\title{
Studi Ketahanan Benturan pada Komposit Serat Rami-Epoksi dan Polimer Blend ABS- PP untuk Aplikasi Bahan Alternatif Soket Prostesis
}

\author{
Fadli Robiandi ${ }^{1}$, Ikal $M^{2}$, Menasita $M^{3}$ \\ ${ }^{1}$ Program Studi Fisika, JSTPK, Institut Teknologi Kalimantan, Balikpapan. Email: fadlirobiandi@itk.ac.id \\ ${ }^{2}$ Program Studi Fisika, JSTPK, Institut Teknologi Kalimantan, Balikpapan. Email: 01151007@itk.ac.id \\ ${ }^{3}$ Program Studi Fisika, JSTPK, Institut Teknologi Kalimantan, Balikpapan. Email: menasita@itk.ac.id
}

\begin{abstract}
Fabrication of rami fiber based on composite with epoxy matrixs and polymer blend of ABS-PP for alternative prosthetic soket application have been conducted. This research attempts to analyze impact resistance of ramiepoxy based on composite and polymer blend base ABS-PP. Those sample was made by hand lay up and simple hot casting methode at a temperature of $250{ }^{\circ} \mathrm{C}$. rami-epoxy based on composite and polymer blend samples with volume fraction variation $0 \%, 25 \%, 50 \%$ and $75 \%$. The result of charpy impact test showed an increase in impact energy along with an increase in the volume fraction of rami. In other hand, an increase in ABS volume fraction could reduce the impact energy of polymer blend samples. From impact testing result, both samples showed brittle like-structure. Broken fiber with low fiber pull out mechanism was found out in rami-epoxy composite samples. Polymer blend samples showed pull out mechanism on ABS grain.

Keywords: composite, impact energy, impact testing, prosthesis
\end{abstract}

\begin{abstract}
Abstrak
Pembuatan komposit serat rami dengan matriks epoksi dan polimer campuran ABS dengan PP sebagai material alternatif soket prostesis telah dilakukan. Penelitian ini bertujuan untuk mempelajari ketahanan benturan (impact) pada kedua jenis komposit tersebut. Komposit serat rami-epoksi diprabikasi dengan metode hand lay up dan komposit PP/ABS difabrikasi dengan metode simple hot casting pada temperatur $250^{\circ} \mathrm{C}$. Sampel komposit serat rami dan polimer blend ABS-PP dibuat dengan variasi fraksi volume 0\%, 25\%, 50\% dan 75\%. Dari hasil uji benturan metode charpy komposit serat rami-epoksi mengalami peningkatan energi impact seiring dengan peningkatan fraksi volume serat rami. Hasil ini berkebalikan dengan komposit ABS-PP yang mengalami penurunan energi impact seiring bertambahnya fraksi volume ABS. Bentuk patahan komposit serat rami-epoksi dan polimer ABS-PP adalah britle. Pada sampel serat rami-epoksi terjadi mekanisme fiber break dan sedikit fiber pullout. Pada sampel polimer ABS-PP terjadi mekanisme pull out pada butir ABS.
\end{abstract}

Kata Kunci: energi impact, komposit, prostesis, uji benturan,

\section{Pendahuluan}

Prostesis merupakan alat buatan yang dibuat untuk menggantikan fungsi bagian tubuh manusia akibat kerusakan, trauma, dan lainnya. Prostesis biasanya didesain menyerupai bentuk bagian tubuh manusia. Prostesis terdiri beberapa bagian salah satunya adalah soket prostesis. Soket merupakan bagian penghubung antara prostesis kaki atau tangan dengan bagian tubuh yang masih tersisa.

Bahan baku untuk soket prostesis konvensional biasanya menggunakan bahan polimer, seperti: polietilena (Park, 2002), polipropelina (Goh, 2002), akrilik, Akrilonitril butadiena stirena (ABS) dan poliuretan (Young, 2014). Bahan polimer tersebut biasanya dihasilkan dari pengolahan minyak bumi yang merupakan sumber daya alam takterbarukan. Sifat mekanik bahan polimer ini lebih rendah dibanding metal, sehingga membutuhkan perlakuan tertentu untuk meningkatkan kekuatan mekaniknya.

Komposit merupakan material potensial yang dapat dijadikan bahan pembuatan prostesis (Nurhanisah, 2017). Komposit terdiri dari matriks atau pengikat dan filler yang berfungsi sebagi pengisi atau reinforced. Kelebihan komposit adalah sifat mekanik yang didapatkan lebih baik dari sifat pada material pembentuknya. Dengan demikian, kelebihan sifat mekanik dari dua jenis material atau lebih dapat digabungkan. Matrik dan filler pada komposit dapat berupa material polimer sintetis atau bahan alami. Komposit yang menggunakan bahan alam disebut dengan biokomposit. 
Biokomposit merupakan komposit yang terbentuk dari matrik ataupun filler dari bahan alami. Salah satu kelebihan komposit jenis ini adalah bahan mentah komposit dapat dibudidayakan sehingga ketersediannya dapat diperbarui. Bahan alam memiliki kekuatan yang mekanik yang cukup baik. Bahan alam yang dapat dimanfaatkan sebagai filler biokomposit adalah rami (Tresna, 2009).

Tanaman rami dikenal dengan nama ilmiah Boehmeria nivea $(L)$ Groud merupakan tanaman dengan rumpun yang dapat menghasilkan serat dari kulit kayunya. Serat rami mempunyai beberapa keunggulan dibandingkan serat kayu lain seperti kekuatan tarik, daya serap air, tahan terhadap kelembapan serta relatif lebih ringan dari serat sintetis. Rami mudah dikembangbiakkan di daerah tropis, tahan terhadap penyakit dan hama. Dengan demikian, rami merupakan bahan alam yang potensial sebagai bahan baku komposit untuk soket prostesis (Agustinus, 2009).

Beberapa penelitian telah dilakukan tentang pemanfaatan rami sebagai bahan biokomposit seperti pemanfaatan komposit berbasis rami sebagai bahan alternatif soket prostesis (Tresna, 2009), material biodegredable (Kumar. 2012), (Krasowska, 2010), material komposit untuk aplikasi flame retardant ( Yan, 2017). Serat rami dijadikan sebagai bahan penguat (reinforced) dan matrik yang digunakan berupa polimer sintetis seperti poliester dan epoksi. Pada komposit tersebut biasanya dilakukan uji tarik untuk mengetahui kekuatan tarik. Selain kekuatan komposit terhadap tarikan, diperlukan kemampuan komposit rami terhadap ketahanan benturan. Pada penelitian ini akan dilakukan uji benturan (impact) terhadap komposit rami bermatrik epoksi dan polimer blend polipropilena (PP) dengan akrilonitril butadiena stirena (ABS) sebagai pembanding.

\section{Metode}

Pada proses pembuatan sampel komposit serat rami-epoksi dan polimer blend ABS-PP dilakukan beberapa tahapan, seperti: persiapan bahan, pembuatan sampel, pengujian impact dan pengamatan struktur.

\subsection{Persiapan bahan}

Serat rami yang digunakan pada penelitian ini diperoleh dari pasar tradisional di Balikpapan. Polimer Polipropilena (PP) dan Akrilonitril butadiena stirena (ABS) yang digunakan dalam penelitian ini diproduksi oleh PT. Chandra Asri Petrochemical. Tbk. Matrik epoksi diperoleh dari toko kimia lokal. Pada tahap preparasi, dilakukan proses alkalinisasi dengan larutan $\mathrm{NaClO} 5 \%$ selama 24 jam terhadap material serat rami. Hal ini dilakukan untuk menghilangkan lapisan lignin dan pengotor lainnya dari permukaan serat, sehingga serat lebih bersifat hidrofilik dan dapat berikatan kuat dengan matrik (Purboputro, 2017).

\subsection{Pembuatan sampel}

Pembuatan sampel komposit serat rami-epoksi dan polimer blend ABS-PP mengacu pada ISO 197-1 untuk uji impact, dengan ukuran panjang $11 \mathrm{~cm}$, lebar $1 \mathrm{~cm}$ dan tinggi sampel $1 \mathrm{~cm}$.

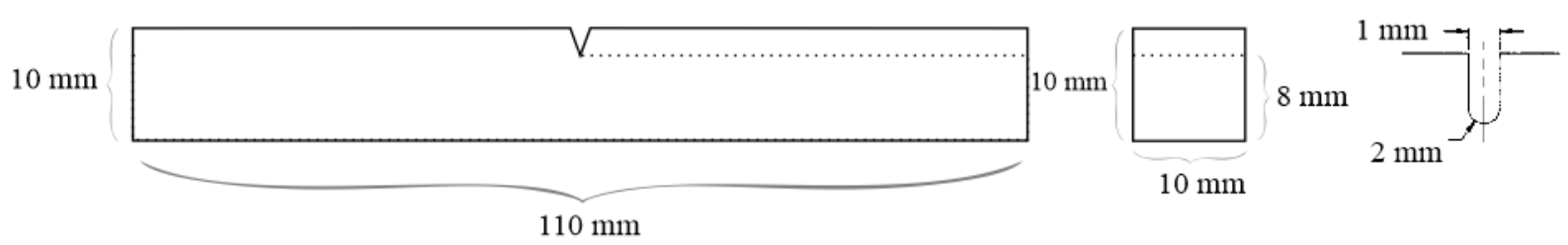

Gambar 1: sketsa bentuk sampel uji impact

Metode yang digunakan untuk pembuatan komposit serat rami-epoksi adalah hand lay up. Pada proses fabrikasi sampel ini, serat-serat rami disusun secara paralel atau sejajar. Matriks epoksi pada pembuatan sampel ini merupakan campuran dari epoksi resin dan hardener. Rasio antara resin dan hardener yang digunakan adalah 1:1. Variasi fraksi volume antara epoksi dengan serat rami adalah $0 \%, 25 \%, 50 \%$ dan $75 \%$.

Metode yang digunakan untuk pembuatan polimer blend ABS-PP adalah simple hot casting. Pada proses ini polimer ABS dan PP dicampur dalam cetakan yang terbuat dari logam aluminum. Campuran polimer tersebut dipanaskan pada temperatur sekitar $235^{\circ} \mathrm{C}$ selama 10 menit. Temperatur pada cetakan 
dimonitor dengan menggunakan termokopel digital. Variasi fraksi volume antara PP dan ABS dibuat sama dengan variasi pada sampel komposit rami-epoksi.

\subsection{Pengujian Impact dan pengamatan struktur}

Pengujian benturan menggunakan alat uji impact tipe charpy produksi ITS (Institut Teknologi Sepuluh November) seperti yang ditinjukkan gambar berikut :

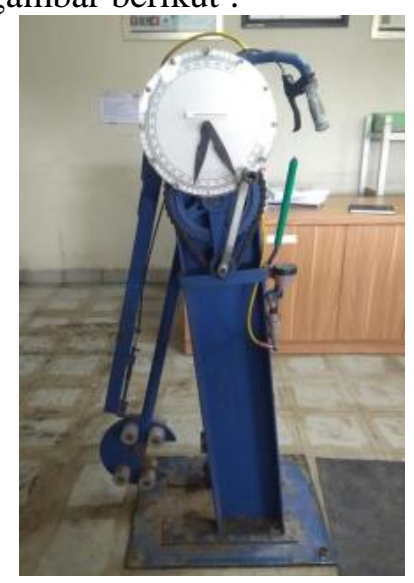

Gambar 2: Alat uji impact

Dari data hasil pengujian didapatkan energi impact dengan menggunakan persamaan berikut :

$$
E=\operatorname{Mgl}(\cos \alpha-\cos \beta)
$$

Dimana :

$\mathrm{E}=$ energi impact $(\mathrm{J})$

$\mathrm{M}=$ massa beban $(\mathrm{kg})$

$1=$ panjang lengan alat uji $(\mathrm{m})$

$\mathrm{g}=$ percepatan gravitasi $\left(\mathrm{m} / \mathrm{s}^{2}\right)$

$\alpha=$ sudut awal sebelum benturan

$\beta=$ sudut setelah benturan

Pengamatan struktur sampel setelah pengujian impact menggunakan mikroskop optik. Mikroskop optik yang digunakan dalam penelitian ini adalah mikroskop digital dengan fokus manual dan dapat dihubungkan dengan komputer atau laptop. Pengamatan dilakukan melalui layar monitor pada laptop terhadap penampang lintang sampel pada bagian patahan setelah pengujian impact.

\section{Hasil dan Pembahasan}

Pengujian impact menggunakan mekanisme perubahan energi potensial menjadi kinetik, dan kembali lagi menjadi energi potensial. Penurunan energi potensial setelah benturan antara beban dengan sampel pada proses pengujian impact menunjukkan adanya sebagian energi yang digunakan untuk mendeformasi sampel. Ketahanan terhadap benturan pada sampel dapat diukur dari besarnya energi kinetik yang diserap oleh bahan tersebut hingga patah (failure).

Dari hasil pengujian impact pada matrik epoksi, PP dan ABS, polimer PP memiliki ketahanan benturan yang paling tinggi dibandingkankan sampel epoksi dan ABS. Hal ini ditunjukkan oleh gambar 3 di mana polimer PP memiliki energi impact yang lebih tinggi dengan nilai 2,2 J. Harga energi impact menunjukkan seberapa besar energi yang diserap dari energi mekanik alat pengujian oleh sampel hingga sampel mengalami deformasi dan rusak. Sehingga peningkatan energi impact berbanding lurus atau proporsional dengan ketahanan benturan. 


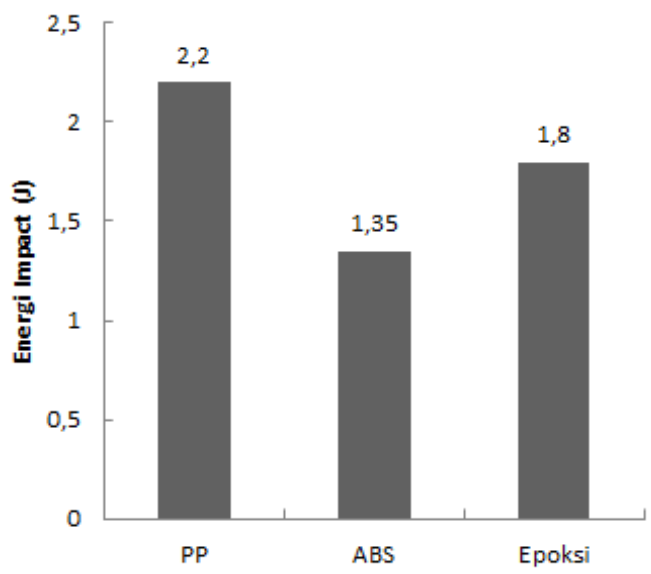

Gambar 3: Grafik energi impact pada polimer PP, ABS dan epoksi

Sampel epoksi, PP dan ABS bersifat getas atau brittle, hal ditunjukkan oleh Gambar 4. Pada sampel PP dan ABS terlihat adanya void atau pori, pori terbanyak dimiliki oleh sampel ABS. Hal ini menunjukkan adanya udara yang terjebak selama proses pembuatan sampel. Gambar 4.c dan 4.d menunjukkan perbedaan karakteristik polimer PP dengan ABS saat mengalami proses pemanasan pada temperatur $235^{\circ} \mathrm{C}$, di mana polimer PP mampu melebur dengan baik dan mampu mengisi ruang pada cetakan. Di lain pihak, polimer ABS belum dapat melebur dengan sempurna sehingga masih menyisakan butiran pelet speris yang saling menempel membentuk agregat, dan masih menyisakan ruang yang belum terisi, sehingga menyebabkan terbentuknya pori pada sampel.
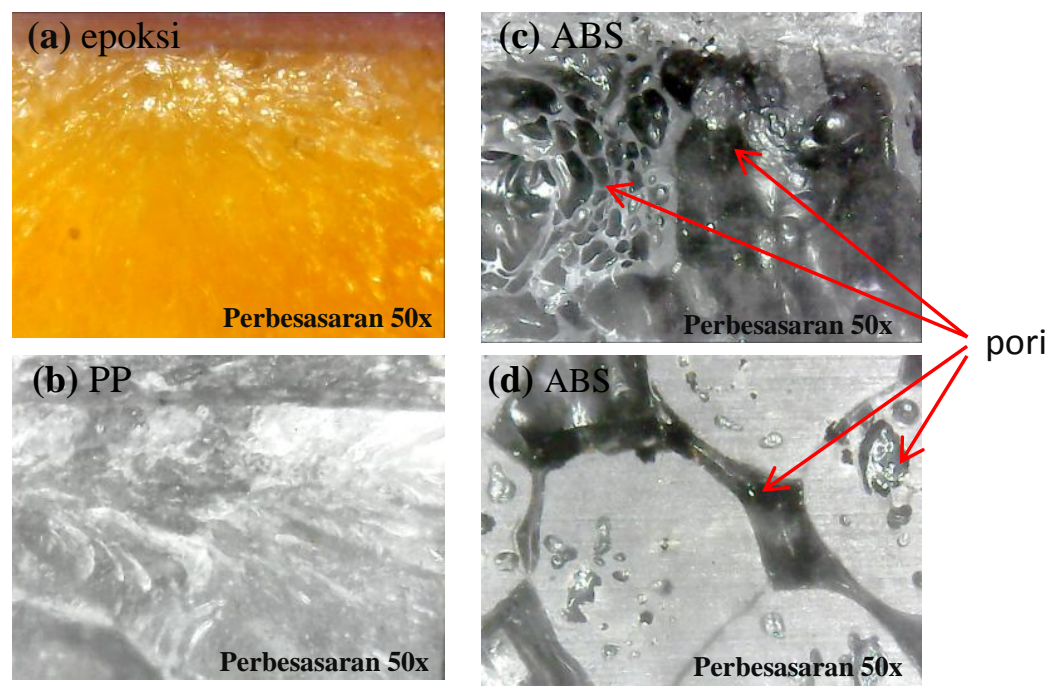

Gambar 4: Bentuk mode patahan sampel matriks dan polimer.

Dari hasil pengujian impact, hubungan antara fraksi volume serat rami dengan energi yang diserap sampel atau energi impak ditunjukkan oleh gambar 5.a. Peningkatan fraksi volume serat rami pada sampel komposit rami-epoksi juga diikuti oleh peningkatan energi yang diserap sampel. Penambahan volume serat rami terhadap matrik epoksi hingga 75\% dapat meningkatkan ketahanan terhadap benturan. Nilai energi yang diserap sampel tertinggi pada sampel komposit rami-epoksi berada pada fraksi volume filler $75 \%$, yaitu: $1,85 \mathrm{~J}$. 


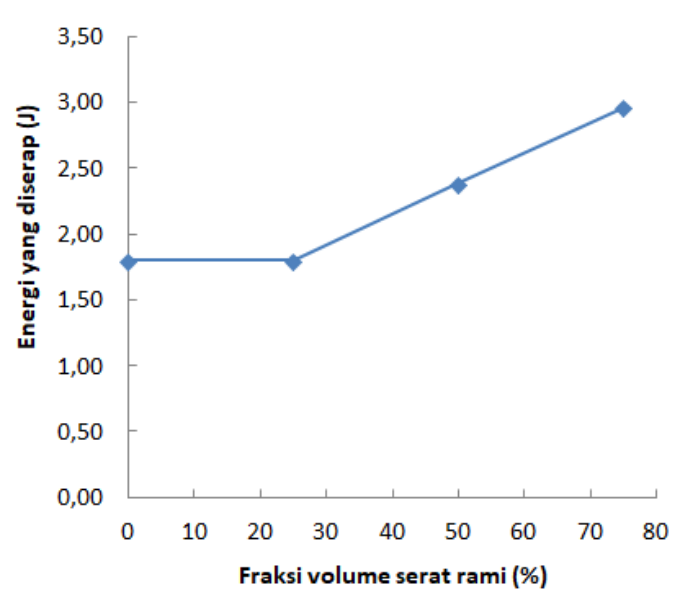

a) sampel komposit serat rami-epoksi.

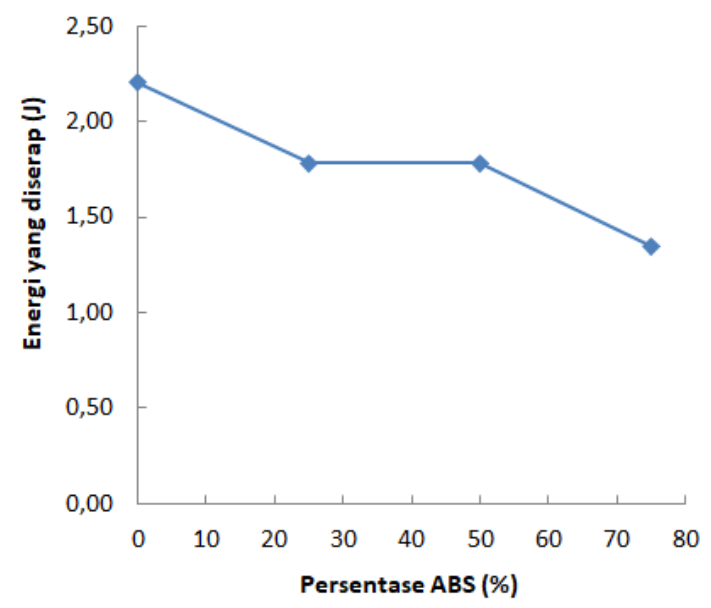

b) sampel polimer blend ABS-PP

Gambar 5: Grafik hasil uji impact.

Serat rami berikatan kuat dengan matrik epoksi, hal ini ditunjukkan oleh gambar 6.a dari gambar tersebut tampak terjadi mekanis putusnya serat (fibre break) dan sedikit serat rami yang mengalami mekanisme fibre pull out atau mekanisme tercabutnya serat dari matriks. Hal ini menunjukkan beban atau benturan pada sampel tersebut dapat didistribusi dan ditransferkan pada serat rami. Saat matrik epoksi mengalami kegagalan (failure), serat rami tidak dapat menahan beban sehingga sampel mengalami proses patah secara bersamaan dan serat menjadi putus atau mengalami fiber break. Dari gambar 6.a, terlihat komposit serat rami-epoksi bersifat brittle.

Hasil uji impact pada sampel polimer blend ABS-PP menunjukkan perilaku yang berkebalikan dengan sampel komposit serat rami/komposit. Peningkatan persentase ABS diikuti dengan penurunan energi yang diserap sampel. Penambahan volume polimer ABS hingga 75\% dapat menurunkan ketahanan sampel terhadap benturan. Hubungan antara persentase jumlah volume ABS dengan energi yang diserap sampel ditunjukkan oleh gambar 5.b.

Gambar 6.b menunjukkan interaksi PP dengan ABS pada sampel tidak membentuk ikatan yang kuat. Kedua polimer tersebut tidak dapat bercampur dengan baik membentuk polimer blend yang kuat. Pada sampel tersebut, ABS tidak melebur namun membentuk butiran pelet speris dan cenderung saling terpisah. Polimer PP mampu melebur dengan baik dan tersebar diantara ABS, sehingga pada sampel membentuk struktur yang menyerupai komposit, seperti yang ditunjukkan oleh gambar 6.b.
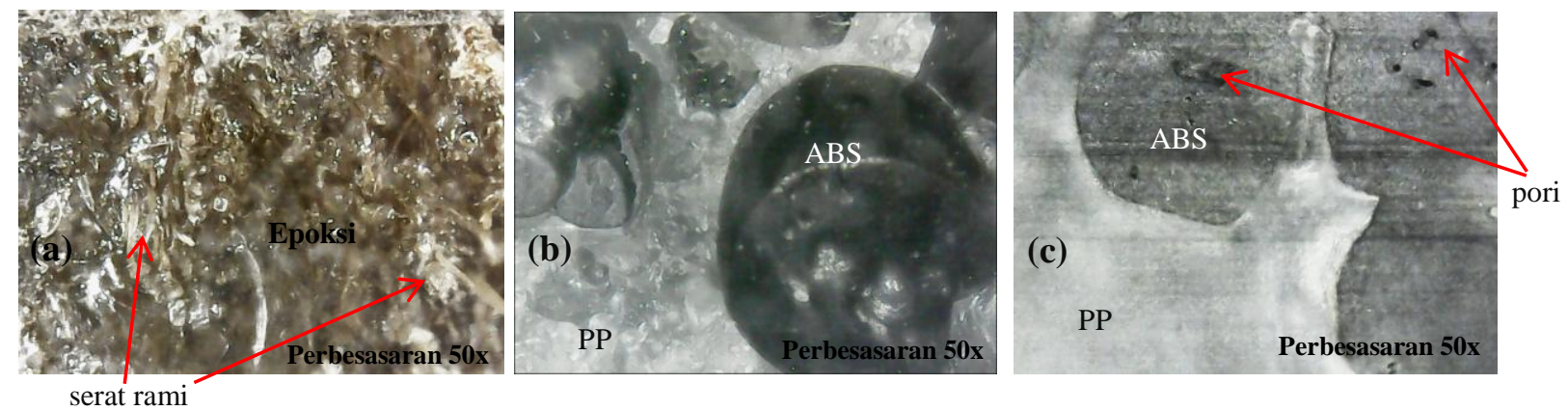

Gambar 6: bentuk failure mode pada sampel. (a) komposit rami-epoksi. (b),(c) polimer ABS-PP.

Ikatan yang tidak kuat mengakibatkan menurunnya kekuatan mekanik sampel polimer blend. Hal ini berdampak saat terjadi benturan pada sampel, beban yang diterima sampel tidak terdistribusi dengan baik sehingga tidak terjadi proses patah secara bersamaan. Polimer PP mengalami mekanisme failure atau patah, sedangkan pada ABS terjadi mekanisme pull out. Selain itu, pada butiran ABS terbentuk 
pori atau void, hal ini menunjukkan adanya gas yang terperangkap selama proses pemanasan pada metode hot casting hal ini terlihat pada struktur polimer blend ABS-PP yang ditunjukkan gambar 4.c

\section{Kesimpulan}

Berdasarkan uji impact, material epoksi, PP dan ABS bersifat getas. Sampel ABS yang fabrikasi dengan metode simple hot casting pada temperatur $235{ }^{\circ} \mathrm{C}$ menghasilkan struktur agregat yang berpori. Sedangkan PP mampu melebur dengan baik sehingga menghasilkan sampel yang lebih padat dengan pori yang lebih sedikit. Penambahan jumlah ABS dapat menurunkan ketahanan impact pada bahan polimer blend ABS-PP. Sampel ABS 0\% PP 100\% memiliki energi impact tertinggi dengan nilai 2,2 J. Polimer blend ABS-PP mengalami mekanisme pull out setelah pengujian impact. Peningkatan fraksi volume serat rami hingga $75 \%$ dapat meningkatkan ketahanan benturan pada bahan komposit serat ramiepoksi dengan nilai energi impact tertinggi 1,85J. Serat rami dapat berikatan dengan baik dengan epoksi, hal ini ditunjukkan dengan mekanisme fiber pull out yang sedikit dan lebih banyak fiber break saat sampel patah.

\section{Ucapan Terimakasih}

Terima kasih kepada Kementrian Riset, Teknologi dan Pendidikan Tinggi, Direktorat Riset dan Pengabdian Masyarakat yang telah memberikan hibah dana penelitian melalui skema Penelitian Dosen Pemula Tahun 2018 sehingga penelitian ini dapat terlaksana. Penulis juga mengucapkan terima kasih kepada Institut Teknologi Kalimantan, khususnya LPPM ITK dan semua pihak yang membantu pelaksanaan penelitian ini.

\section{Daftar Pustaka}

Agustinus, P.I., Tresna P.S., Widjajalaksmi K., (2009). Komposit Lamina Rami Epoksi Sebagai Bahan Alternatif Socket Prosthesis. Jurnal Teknik Mesin. Vol. 11. No.1. pp: 41-45.

Goh, J.C., P.V.S. Lee. (2002). Structure Integrity of Polypropylene prosthetic sokets manufacturing using the polymer deposition technics. NCBI. Issue 216(6). pp: 359-68.

Kumar,A., M.S. Sreekala., S.Arun. (2012). Studies on Properties of Bio-Composites from Ecoflex/Ramie FabricMechanical and Barrier Properties. Journal of Biomaterials and Nanobiotechnology. Vol:3. pp: 396-404.

Krasowska, K., J. Brzeska., Maria R., Helena J., M.S. Sreekala, Koichi G., T.Sabu. (2010). Environmental Degredation of Ramie Fibre Reinforced Biocomposites. Polish J. of Environ. Stud. Vol:19. pp: 937-945.

Nurhanisah, M.H., N. Saba., M. Jawaid. (2017). Green Biocomposite Design and Aplication. Springer.

Park H.K., Dujovny M., Diaz F.G., Guthikonda M., (2002). Biomedical Properties of High Density Polyethelene for Pterional Prosthetic. NCBI. 24(7):671-6.

Purboputro, P.I., Agus H. (2017). Analisis Sifat Tarik dan Impak Komposit Rami dengan Perlakuan Alkali Dalam Waktu 2,4,6 dan 8 Jam Bermatriks Poliester. Jurnal Ilmiah Teknik Mesin UMS. Vol.18. No.2. pp: 64-75.

Tresna, P.S., Widjajalaksmi K., Agustinus P.I. (2009). Karakteristik Komposit Lamina Serat Rami Epoksi Sebagai Bahan Alternatif Soket Prostesis. Makara Teknologi. Vol.13. No.3. pp:96-101.

Yan.H., Nannan Li., Jie Chneg., Pingan Song., Zhengping Fang., Hao Wang. (2017). Fabrication of flame retardant benzoxazine semi- biocomposites reinforced by ramie fabrics with bio- based flame retardant coating. Polymer Composites. Vol:39. pp:480-488

Young He, Guang Huai, Jian Zhong Fu (2014). Fabrication of Low Cost Soft Tissue Prostheses With the Desktop 3D Printer. Scientific Reports. Vol: 4. pp: 69-73. 